\title{
Farmers' Participation in Agroforestry System in Northwestern Nigeria
}

\author{
Danjuma, M.N. ${ }^{1, *}$, Mohammed, S. ${ }^{2}$ and Karkarna, M.Z. ${ }^{3}$ \\ ${ }^{1,2}$ Department of Geography, Bayero University Kano, Nigeria \\ ${ }^{3}$ Department of Environmental Management, Bayero University Kano, Nigeria \\ Corresponding Author: *mndanjuma.geog@buk.edu.ng
}

\begin{abstract}
The aim of this study is to assess agroforestry practices in Northwestern Nigeria with a view to bringing to light some salient features of the system for maximising benefits and improving livelihoods of smallholder farmers in the study area. A total of one hundred and sixty six smallholder farmers were sampled using random technique from five hundred and fifty farmers' listed by the contact forum in the study area. Questionnaire was administered to the one hundred and sixty six smallholder farmers with a view to examining the level of farmers' participation in agroforestry in six villages namely Kabobi and Garki in Katsina State, Bulangu and Abonabo in Jigawa State, Bobo in Zamfara State and Gulma in Kebbi State. Interview was also conducted with ten farmers in Bulangu, Kabobi and Gulma to provide explanations on the limitation to acceptance of agroforestry innovations in the study area. Data collected with the questionnaire was analysed using simple percentage and frequency in order to measure dispersion among sampled farmers. Data collected from the interview was coded, transcribed and presented in textual form in the paper. Result of the study revealed that seven agroforestry systems (alley cropping, boarder line planting, scattered planting, woodlot, apiculture, orchard and home garden) were practiced in the area. Orchard and home garden were not practiced in Kabobi, the northern most of the villages. It also indicated farmers' level of participation for the seven identified technologies as follows: Alley cropping $(25.63 \%)$, boarder line planting (16.25\%), scattered trees on farmland (36.25\%), woodlot $(1.25 \%)$, orchard (1.88\%), apiculture (8.75\%) and home gardens (10.00\%). The key factors limiting acceptance of innovations include: l) lack of tree seedling (25.00\%), land tenure issues (17.50\%), long tree gestation period of indigenous species (50.63\%) and insect attack (06.88\%). This study recommended that farmers should be educated more on agroforestry technologies through mass media programmes and ICT.
\end{abstract}

Keywords: Land management, Alley cropping, Livelihood, Smallholder

\subsection{Introduction}

Agroforestry is a collective name for land-use systems and technologies where woody perennials (trees, shrubs, palms, bamboos, etc.) are deliberately used on the same land-management units as agricultural crops and/or animals, in some form of spatial arrangement or temporal sequence (Lundgren and Raintree, 1982). According to Leakey (1996) agroforestry is a dynamic, ecologically based natural resource management system that, through the integration of trees on farms and in the agricultural landscape, diversifies and sustains production for increased social, economic and environmental benefits for land-users at all levels. This definition is employed in this study.

Agroforestry is not new system. It has been practiced for millennia by many cultures and societies in traditional farming systems throughout the world (Cook and Grut, 1989; Garrity, 2006). The World Bank estimates that 1.2 billion people practice some form of agroforestry on their farms and in their communities (World Bank, 2004). The system provides a range of goods and services such as food, fodder, fuelwood, and timber to farmers (ICRAF, 2009). It also offers one of the most promising 
technological options for reversing soil degradation, restoring tree cover, and improving agricultural productivity in Africa (Mbow et al., 2014).

Being a feature of agriculture landscapes throughout the world, agroforestry was brought into the limelight due to concerns about the sustainability of agricultural development and the apparent rapid depletion of the natural resources (FAO, 2004). The system has drawn the attention of researchers due to its capacity to reduce the poverty and land degradation, improve food security and mitigate the climate change (Ahmad et al., 2017). In the last three decades, agroforestry has been widely promoted in the tropics as a natural resource management strategy that attempts to balance the goals of agricultural development with the conservation of soils, water, local and regional climate, and more recently, biodiversity (Izac and Sanchez, 2001). In the West African savanna, it is common for farmers to retain useful trees (which may also be difficult to fell and resistant to fire) when preparing a plot for cropping, thereby creating park-like landscapes of scattered trees between crop fields and rangelands that are typical of this region (Boffa, 1999). It is particularly significant in Nigeria, but the extent to which it is practised varies from region to region. The taungya system was first introduced to Nigeria in 1928 from Burma in a silvicultural experiment at Sapoba (Edo State) is widely adopted agroforestry practice in the rainforest and derived zones of Nigeria. In the Sahel region, however, scattered trees on cultivated or recently fallowed land form a characteristic land-use system commonly referred to as 'Parklands'. The most important and dominant tree species in used in this system include Faidherbia albida, Butyrespermum parkii, Parkia biglobosa, Adansonia digitata, Tamarindus indica, Acacia tortilis and Prosopis africana (Ado, 2012).

The degradation of forest resources poses serious challenges to the rural people who depend on forest resources for livelihoods. This has widened the gap between the demand and supply of forest products in Nigeria. The fundamental concern is however, finding alternative options to support rural livelihoods as well as reducing resource depleting due to shifting cultivation. After all the primary reason for forest destruction is man's ever-increasing demand for more land for producing food (Nair, 1982) and agroforestry offers possibilities for controlling that.

Nao (1978) described Nigeria as one of the countries with the most successful examples of agroforestry experiments particularly the agrosilvicultural types. Recently, other agroforestry practices have evolved in Nigeria. The most popular which Nair (1993) termed agrisilviculture and agrihorticulture are most accepted systems. Similarly, many of these agroforestry technologies have been trialled at research stations since 1980 and also on farms since 1984 in collaboration with farmers (Franzel et al., 2002). This indicated that a lot of studies were conducted on agroforestry in Nigeria. Some works that have covered the northern Nigeria or section include Chup, 2004; Adewusi, 2006 and Chukujekwu, 2010. Others are Kabir, 2011 and Ado, 2012. The aforementioned works showed that agroforestry is widely practiced in the northern Nigeria because of its potential on improving livelihood of rural farmers. Arguably, no work has studied agroforestry at regional scale in Northwestern Nigeria in recent time. Because of lack of readily usable and comprehensive information to guide farmers in the study area, this study assessed agroforestry practices in Northwestern Nigeria with a view to bringing to light some salient features of the system for maximising benefits and improving livelihoods in the area.

\subsection{Study area}

Northwestern Nigeria encompasses three distinct geographic entities namely the Sokoto-Rima Basin, the Kano Region and the North Central Highlands (Udo, 1970). Of Nigeria's total area of 923,768 $\mathrm{km}^{2}$ (Federal Government of Nigeria, 2012), Northwestern region occupies 226,662 $\mathrm{km}^{2}$ which encompasses seven states namely Kaduna, Kano, Jigawa, Katsina, Zamfara, Sokoto and Kebbi (Figure 1). 


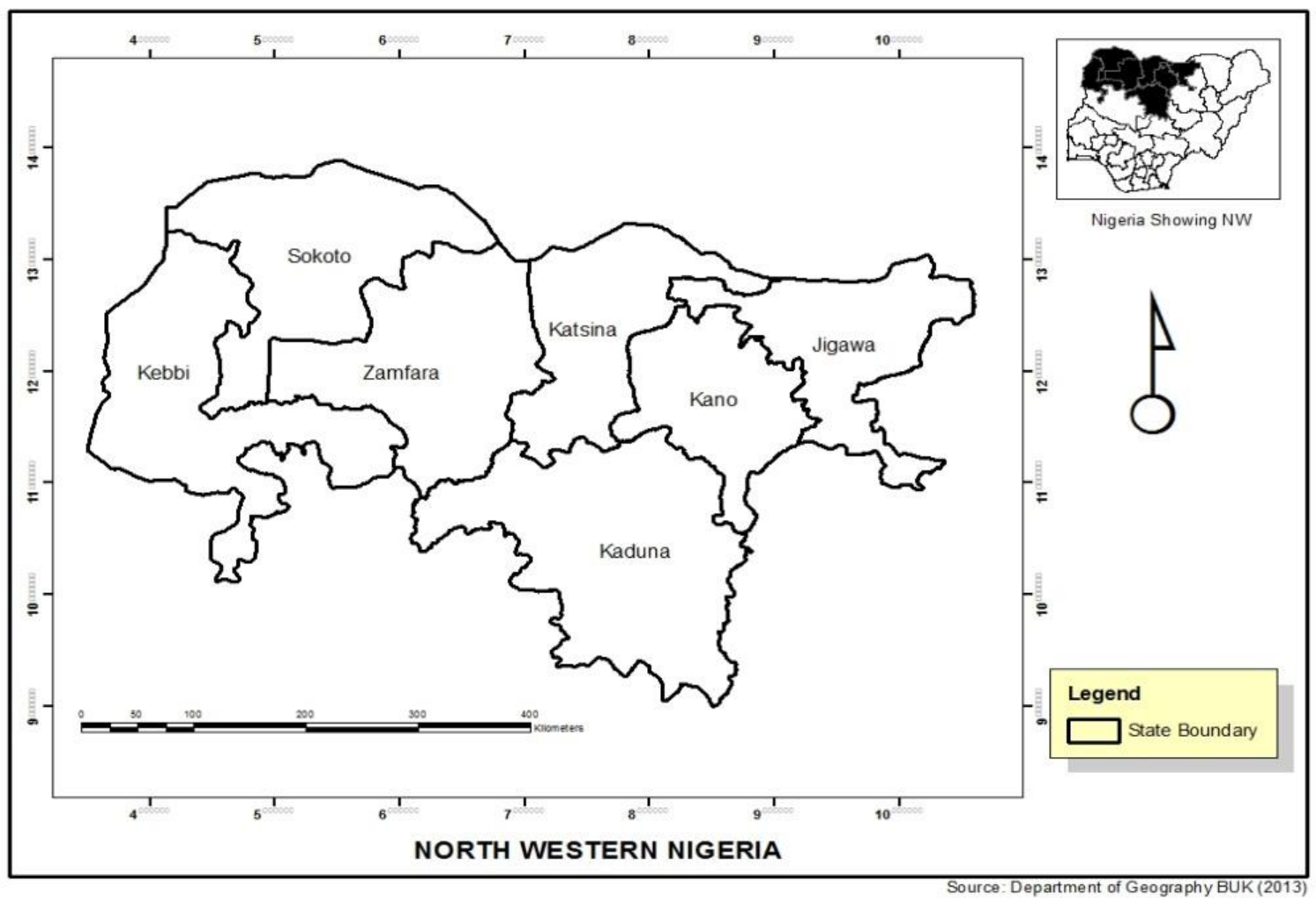

Figure 1: Northwestern Nigeria

Four states which this study covered namely Jigawa, Katsina, Zamfara, and Sokoto share common international border with the Niger Republic to the north, a major part of West African dryland. Total population for the study area was 17,144,135 (National Population Commission, 2006).

Climate of Northwestern Nigeria is the tropical wet and dry type. It is coded as 'Aw' by Koppen in which distinctive wet and dry seasons are caused by the fluctuations of the Inter-tropical convergence zone (ITCZ) or the Inter-tropical Discontinuity (ITD) south to north to bring rainy season and north to south to bring dry season. Climatic elements vary greatly from the southern tip through the central and extreme northern parts of the region (Iloeje, 1981). Average annual rainfall in dryland of Nigeria varies from $500 \mathrm{~mm}$ in the north-eastern part to $1000 \mathrm{~mm}$ in the southern sub-area, but it is unreliable in many parts (Hess et al., 1996). A major climatic influence in the region is the periodic drought associated with periodic rainfall deficiencies (Swindell, 1982) which affect the vegetation growth especially of annuals.

Vegetation varies dramatically at both the national and local level in relation to climate, soil, elevation, and human impact on the environment in Nigeria. Northern Nigeria falls within the Sudan Savanna zone of the country which is distinguished by large expanse of grasslands with widely spaced trees of varying heights and diversity (Danjuma, 2017). This Savanna belt is found dominating the Sokoto Plains across to the Chad Basin, covering over a quarter of the country's land area. As a result of low rainfall and poor soil fertility, the natural vegetation of the northwestern Nigeria is made up of mainly thorn shrubs and trees dominated by grasses (Breman and de wit, 1983). Some of the most frequent species in this environment are: Hyphaene thebaica, Parkia biglobosa, Adansonia digitata, Faidherbia albida, Tamarindus indica, Borassus aethiopum, Prosopis africana, Balanite aegyptiaca and Acacia nilotica. Exotic species include Acacia senegalensis, Azadirachta indica, Cassia siammea, Dolonix regia, and Eucalyptus camaldulensis (Danjuma, 2017). Northwestern Nigeria is home of farming and livestock breeding (Ileoje, 1981). These two livelihood activities are the major economic activities in northwestern Nigeria, especially in rural areas. The dominant crops grown are staple ones including guinea corn, millet, maize and tubers (Swindell, 1982). The existence of these ecological patterns in Nigeria: the high forest in the south and the savanna region in the north resulted to the adoption of various types of agroforestry in the country. 


\subsection{Methodology}

This study covered six villages in the dryland of Northwestern Nigeria namely: Bulangu and Abonabo in Jigawa State, Kabobi and Garki in Katsina State, Bobo in Zamfara State and Gulma in Kebbi State (Figure 2).

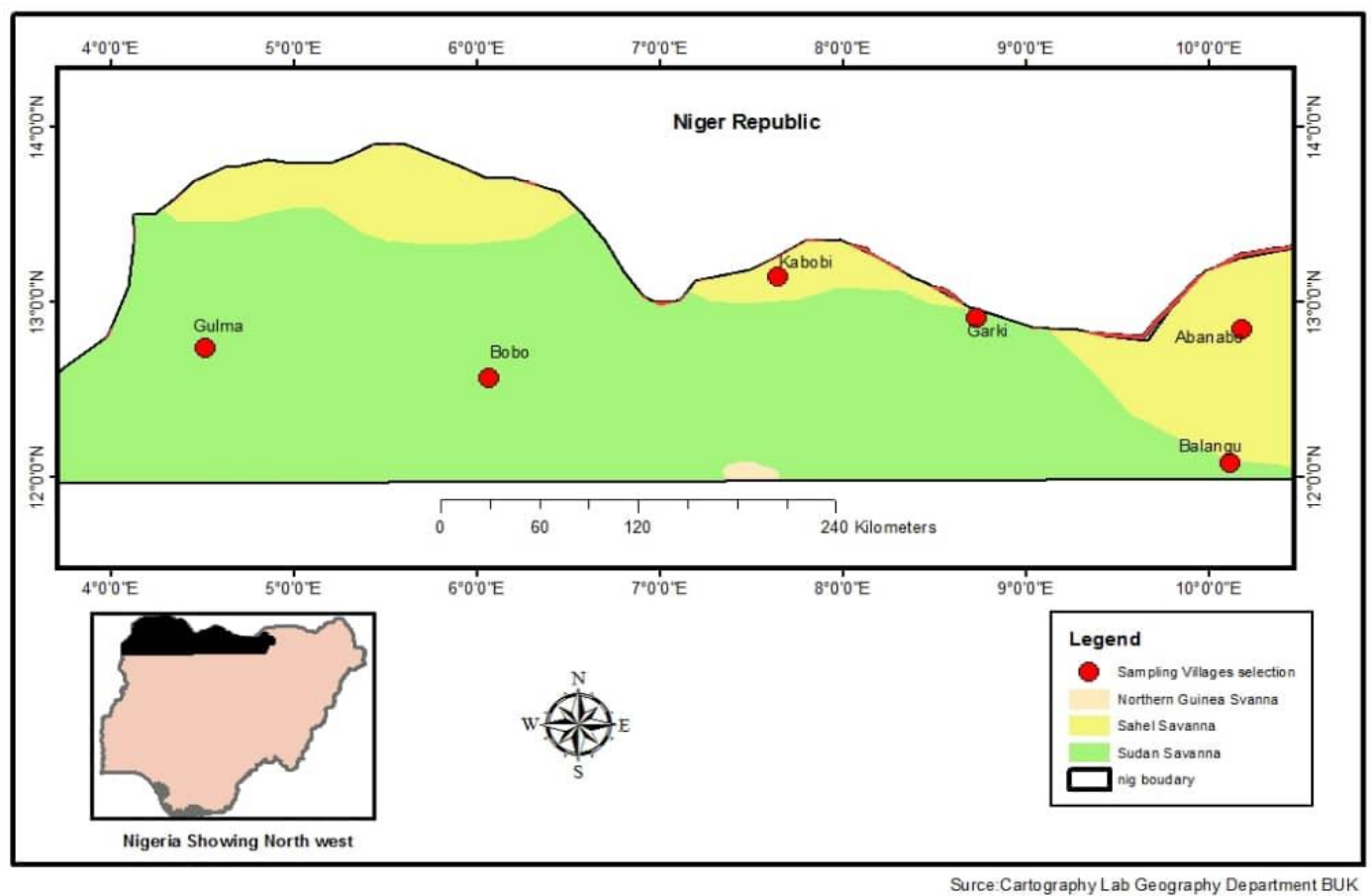

Figure 2: Dryland of Northwestern Nigeria showing study locations

A total of one hundred and sixty six respondents were sampled using random sampling procedure from the sampling frame of five hundred and fifty farmers listed by the contact forum in the study area. The sample is male dominated because out of the six villages studied, five have high male respondents of between $60-90 \%$ as follows: Bulangu (90\%), Abonabo (60\%), Kabobi (50\%), Garki $(80 \%)$, and Bobo (70\%) (Table 1).

A total of ten farmers were also drawn using snowball sampling technique three each in Gulma and Kabobi and four in Bulangu for interview based on the understanding that Bulangu has the highest number of contact farmers; Gulma has the only female dominated sample and Kabobi has equal ratio of female to male.

Table 1: Number and Composition of the Sampled Farmers

\begin{tabular}{|l|l|l|l|l|l|}
\hline SN & Study Village & State & No. of Respondents & No. of Male & No. of female \\
\hline 1 & Bulangu & Jigawa & 43 & 39 & 04 \\
\hline 2 & Abonabo & Jigawa & 23 & 14 & 09 \\
\hline 3 & Kabobi & Katsina & 17 & 09 & 08 \\
\hline 4 & Garki & Katsina & 35 & 28 & 07 \\
\hline 5 & Bobo & Zamfara & 30 & 21 & 09 \\
\hline 6 & Gulma & Kebbi & 18 & 08 & 10 \\
\hline \multicolumn{2}{|l|}{ Total } & & 166 & 119 & 47 \\
\hline
\end{tabular}

Questionnaire was administered to collect information on the level of farmers' participation in agroforestry in the study area. All the questionnaires except six were retrieved two weeks after administration. Interview was also conducted in Bulangu, Garki, and Gulma to provide explanation on the limitation to acceptance of innovations in the study area. 
Data collected with the questionnaire was analysed using simple percentage and frequency in order to measure dispersion among sampled farmers. Data collected from the interview was coded, transcribed and presented in textual form in relevant section of the paper

\subsection{Results and Discussion}

\subsection{Farmers' participation in agroforestry practices in the study area}

Agroforestry practices are numerous. According to Young (1989) there are hundreds, possibly thousands of agroforestry systems in the world but only 20 distinct practices. Result of this study showed that the area comprises seven agroforestry practices (Table 2). As in Table 2, variability existed among the study locations in terms of participation and adoption of the different agroforestry practices.

Of the agroforestry systems depicted in table 2, scattered trees on farmland (36.25\%) and alley cropping (25.63\%) were most extensively practiced in the study area. The system of scattered trees on farmland is widely practiced above all because it requires low investment and labour. Findings on alley cropping supported Adekoya (1997) and Ado (2012) who reported that because of the benefits of leguminous trees and shrubs on improving soil attributes (such as recycling nutrients and controlling erosion on sloping land), alley cropping is widely practiced in Nigeria. This study found that pearl millet and sorghum are cropped in the area between Faidherbia albida and Acacia nilotica for both ecological and socioeconomic benefits. However, many studies including Kang and Wilson (1987) have reported the growing emphasis on the system even in drier areas such as the northern Nigeria because the provision of nutrients through decomposing mulch is possible in these areas despite low rainfall.

Table 2: Level of farmers' participation in agroforestry practices

\begin{tabular}{|l|l|l|l|l|l|l|l|l|l|l|}
\hline \multirow{2}{*}{ SN } & \multirow{2}{*}{ Types of Agroforestry } & \multicolumn{7}{|c|}{ Study Villages } & \multirow{2}{*}{ Total } & \multirow{2}{*}{ Percentage } \\
\cline { 3 - 9 } & & Bulangu & Abonabo & Kabobi & Garki & Bobo & Gulma & \\
\cline { 3 - 9 } & & Freq. & Freq. & Freq. & Freq. & Freq. & Freq. & & \\
\hline 1 & Alley cropping & 12 & 5 & 3 & 10 & 9 & 2 & 41 & 25.63 \\
\hline 2 & Boarder line planting & 8 & 2 & 4 & 3 & 5 & 4 & 26 & 16.25 \\
\hline 3 & $\begin{array}{l}\text { Scattered trees on } \\
\text { farmland }\end{array}$ & 12 & 7 & 7 & 18 & 7 & 7 & & \\
\hline 4 & Woodlot & - & - & 1 & - & 1 & - & 2 & 36.25 \\
\hline 5 & Orchard & 2 & - & - & 1 & - & - & 3 & 1.25 \\
\hline 6 & Apiculture & 4 & 2 & - & 1 & 4 & 3 & 14 & 8.75 \\
\hline 7 & Home gardens & 5 & 4 & - & 2 & 3 & 2 & 16 & 10.00 \\
\hline & Total & 43 & 20 & 15 & 35 & 29 & 18 & 160 & 100.00 \\
\hline
\end{tabular}

Woodlot $(1.25 \%)$, orchard $(1.88 \%)$ and home gardens $(8.75 \%)$ are least practiced. These are very complex systems with a very sophisticated structure and a large number of components. Often woodlot and orchard requires a little more than what nature provides to start and thus farmers would neglect it.

\subsection{Adoption of agroforestry practices in the study area}

There is plethora of information on adoption of agroforestry systems globally. However, it is useful to learn why the farmers continue to practice such indigenous systems because the knowledge of factors influencing adoption helps in establishment of site-adapted system for productive and protective purposes. Result of this study indicated the main factor influencing the adoption of agroforestry in the study area is adequate market and linkages (Table 3). 
Table 3: Factors influencing the adoption of agroforestry practices in the study area

\begin{tabular}{|c|c|c|c|c|c|c|c|c|c|}
\hline \multirow[b]{2}{*}{ SN } & \multirow[b]{2}{*}{ Types of Agroforestry } & \multicolumn{6}{|c|}{ Study Villages } & \multirow[b]{2}{*}{$(\mathrm{nT})$} & \multirow[b]{2}{*}{$\%$} \\
\hline & & $\begin{array}{l}\text { Bulangu } \\
\text { (n) }\end{array}$ & $\begin{array}{l}\text { Abonabo } \\
\text { (n) }\end{array}$ & $\begin{array}{l}\text { Kabobi } \\
\text { (n) }\end{array}$ & $\begin{array}{l}\text { Garki } \\
\text { (n) }\end{array}$ & $\begin{array}{l}\text { Bobo } \\
\text { (n) }\end{array}$ & $\begin{array}{l}\text { Gulma } \\
\text { (n) }\end{array}$ & & \\
\hline 1 & Adequate market and linkages & 33 & 12 & 11 & 27 & 17 & 6 & 106 & 66.25 \\
\hline 2 & Land holding size & 10 & 8 & 4 & 8 & 12 & 12 & 54 & 33.75 \\
\hline 3 & (nT) & 43 & 20 & 15 & 35 & 29 & 18 & & \\
\hline
\end{tabular}

$(\mathrm{n})=$ number of respondents $(\mathrm{nT})=$ total number of respondents

Except in Gulma, the farthest village with reported cases of land tenure abuse, respondents in the study area overwhelmingly indicated that market poses a major threat to the promotion of agroforestry in the study area. This finding corroborates Nikiema (2005) who reported that investment in parkland trees will require a set of criteria that give value to each of the potential plant products. One set of criteria that justifies the investment is the market potential of the plant resources. Olumide (2015) also reported that the important criteria for farmers to grow any new tree species depend among others on assured demand for the produce and ready market outlets, minimum support price, at which tree growing is profitable; and generation of cash surplus as the most powerful incentive for most farmers.

\subsection{Constraints to wider participation of agroforestry practices in the study area}

Despite widespread of potentials of agroforestry, many challenges hinders the scaling up of system in the study area. This work has shown that four factors limit wider participation of farmers in agroforestry in the study area. Long gestation period (50.63\%) and lack of tree seed $(25.00 \%)$ are the main factors limiting the expansion of agroforestry in the study area (Table 4). Finding of this study confirms Ado (2012) who reported that $t$ he fear of delay in returns from long gestation period of trees was a limiting factor for wider participation in agroforestry in the Kano. It is also in line with Kofi et al. (2003) the major constraints to agroforestry in forest fringe communities in Ghana are inadequate education on tree tenureship, lack of seedlings, seasonal occurrence of plant and animal diseases and inadequate knowledge on logging procedures as well as poor marketing system are also major setbacks to the conscious introduction of agroforestry in the study area.

Table 4: Factors limiting participation of innovations

\begin{tabular}{|l|l|l|l|}
\hline SN & Constraints & Number of Farmers & Percentage \\
\hline 1 & Lack of viable seedlings & 40 & 25.00 \\
\hline 2 & Land tenure issues & 28 & 17.50 \\
\hline 3 & Long tree gestation period of indigenous species & 81 & 50.63 \\
\hline 4 & Insect attack & 11 & 06.88 \\
\hline Total & 160 & 100.00 \\
\hline
\end{tabular}

Furthermore, this study suggest that reliable seed supply and distribution system is required for up scaling agroforestry and this is largely missing in Nigeria without which farmers may be discouraged from practice and further investing in it. This finding is in line with Kindt et al. (2006) who reported that some tree species require many years before they produce seeds delaying investment returns and locking producers into selected products.

Result in Table 4 about other factors limiting farmers' participation on agroforestry is in line with findings of several authors such as Adekanye (2002) who hypothesized that land characteristics such as land and tree tenure, as well as tenure rights; social economic and demographic characteristics; and cultural norms affect farmers' willingness to cultivate agroforestry trees. Aturamu (2008) also indicated that under private user rights, farmers are expected to be more willing to invest in the cultivation of fruit trees because they retain exclusive rights to the benefits of such investments. A major hindrance to agroforestry in the Federal Capital Territory has been the existing land tenure system; which has largely restricted accessibility to land and its resources. It has also hindered individual investment in agroforestry in the study area (Chup, 2004). Land tenure and usufruct rights constraints impose some limitation on agroforestry participants in the drylands of eastern Africa (Jama and Zeila, 2005). 


\subsection{Conclusion}

This study indicated that agroforestry is becoming a recognized land use system which is capable of overtaking other conventional methods of land management because of its potentials in improving farmers' livelihood in the study area. Agroforestry is perfectly the most adopted and accepted land use system in Northwestern Nigeria because about 160 farmers engaged in one or other form of the system in the area despite so many limitations. Evidently, this study concluded that alley cropping; boarder line planting and scattered trees on farms are widely practiced while orchard and apiculture are the least. Based on the findings from this study, the following recommendations are made:

1. Farmers should be encouraged to use new agroforestry technologies. As widely expected, many technologies are not popular hence there should be scaling up of campaigns through mass media programmes and ICT else the system will remain traditional despite innovations with win-win promises.

2. Women constitute a very large work force, yet only few participate in agroforestry practices in the study area. This study recommended that there is need to expand the level of participation of women in agroforestry which will improve livelihood and food security of teaming smallholders in the area.

\section{References}

Adekanye, J.A. (2002). Once Upon a Forest: A Masterpiece of Creation. UNAAB Inaugural Lecture Series No. 1.

Adekoya, A.E. (1997). An analysis of Farmers' participation in Agroforestry in Oyo State, Nigeria. Unpublished Ph.D. Thesis, Department of Agricultural Extension, University of Ibadan, Nigeria.

Adewusi, H.G. (2006). Agroforestry Practices and Species Preference in Kano State. Potentials for Improvement. Production Agriculture and Technology, 2 pp. 2-4.

Ado, S.W. (2012). Assessment of Agroforestry Practices in Gezawa Local Government Area of Kano State. Unpublished M.Sc Thesis, Bayero University Kano.

Ahmad, F., Goparaju, L. and Qayum, A. (2017). Agroforestry suitability analysis based upon nutrient availability mapping: a GIS based suitability mapping. AIMS Agriculture and Food, 2(2), pp. 201220. DOI: 10.3934/agrfood.2017.2.201

Aturamu, M.O. (2008). Environmental Protection: The Agroforestry Option. Nigerian Journal of Forestry, 34 (1), pp. 1-6.

Boffa, J. M. (1999). AgroforestryParklands in sub-Saharan Africa. Rome: Food and Agriculture Organization of the United Nations.

Breman, H. and de wit, C.T. (1983).Rangeland productivity and exploitation in the Sahel. Science, 221, pp. 1341-1347.

Chukujekwu, O.M. (2010). Analysis of Agroforestry Practices in Katsina State, Nigeria. A PhD Thesis in the Department of Geography and Planning, University of Jos, Nigeria.

Chup, C.C. (2004). Analysis of Agroforestry Practices in the Guinea Savannah Ecological Zone: A Case Study of the Federal Capital Territory of Nigeria. A PhD Thesis in the Department of Geography and Planning, University of Jos, Nigeria.

Cook, C.C. and Grut, M. (1989). Agroforestry in Sub-Saharan Africa: A Farmer's Perspective. World Bank Technical Paper Number, 11, Washington.

Danjuma, M.N (2017). Vegetation Change in the Dryland of northwestern Nigeria and its Implication for Conservation of Indigenous Plant Species. Unpublished PhD Thesis Department of Geography, Bayero University Kano, Nigeria. 
FAO (2004). State of the World Forest. Food and Agriculture Organisation, Rome.

Federal Government of Nigeria (2012). Great Green Wall for the Sahara and Sahel Initiative: National Strategic Action Plan, Abuja, Nigeria.

Franzel, S., Phiri, D. and Kwesiga, F. (2002). Assessing the adoption potential of improved fallows in eastern Zambia. In: Franzel, S. and Scherr, S.J. (Eds.). Trees on the Farm: Assessing the adoption potential of Agroforestry Practices in Africa. Wallingford, UK: CAB International.

Garrity, D.P. (2006). Science-based agroforestry and the Millenium Development Goals. In: Garrity, D.P., Okono, A., Grayson, M. and Parrott, S. (Eds.). World Agroforestry into the Future. World Agroforestry Centre, Nairobi, Kenya.

Hess, T.M., Stephens, W. and Thomas, G. (1996).Modelling NDVI from decadal rainfall data in the North East Arid Zone of Nigeria. Journal of Environmental Management, 48, pp. 249-261.

ICRAF (2009). Annual Report 2008-2009: Agroforestry - a global land use. World Agroforestry Centre, Nairobi, Kenya.

Iloeje, N.P. (1981). A New Geography of Nigeria. Fifth edition. Longman, Ikeja.

Izac, A.-M. N. and Sanchez, P.A. (2001). Towards a natural resource management paradigm for international agriculture: the example of agroforestry research. Agricultural Systems, 69, pp. 5-25.

Jama, B. and Zeila, A. (2005). Agroforestry in the drylands of eastern Africa: a call to action. ICRAF Working Paper - no. 1. World Agroforestry Centre, Nairobi.

Kabir, U. (2011). Analysis of Agro Forestry Farmers (Tree-Planting) in Giwa Local Government Area, Kaduna State, Nigeria. A Thesis submitted to the Department of Agricultural Economics and Rural Sociology, Ahmadu Bello University, Zaria.

Kang. B.T. and Wilson, G.F. 1987. The development of alley cropping as a promising agroforestry technology. In: Steppler, H.A. and Nair, P.K.R. (eds.). Agroforestry: A Decade of Development. ICRAF, Nairobi, Kenya.

Kindt, R. and Coe, R. (2005). Tree Diversity Analysis. A manual and software for common statistical methods for ecological and biodiversity studies. World Agroforestry Centre (ICRAF), Nairobi.

Kofi, A.F., Joyce, A., Rose, A-D., Mensah, A.K., Samuel, A., Agyei, B.E., et al. (2003).The Potential and Constraints of Agroforestry in Forest Fringe Communities of The Asunafo District-Ghana. Tropenbos International Ghana (TBI-Ghana).

Leakey, (1996). Agroforestry Today: Vol. 8 No. 1: ICRAF, Nairobi, Kenya.

Lundgren, B.O. and Raintree, J.B. (1982). Sustained Agroforestry. In: Nestel, B. (ed.) Agricultural Research for Development: Potential and Challenges in Asia. ISNAR, The Hague, Netherlands.

Mbow, C., Noordwijk, M.V., Luedeling, E. et al. (2014). Agroforestry solutions to address food security and climate change challenges in Africa. Curr Opin Environ Sustain., 6, pp. 61-67.

Nair, P.K.R. (1982). Agroforestry: a sustainable land-use system for the fragile ecosystems in the tropics. Malay. Nat. J., 35, pp. 109-123

Nair, P.K.R. (1993). An Introduction to Agroforestry. Kluwer Academic Publishers, Dordrecht, The Netherlands. 
Nao, T. Van (1978). Agrisilviculture: Joint Production of Food and Wood. Paper Presented at the $8^{\text {th }}$ World Forestry Congress, Jakarta, Indonesia.

National Population Commission, NPC (2006). National Population Census, Federal Government of Nigeria, Abuja.

Nikiema, A. (2005). Agroforestry Parkland Species Diversity: Uses and Management in Semi-Arid West Africa (Burkina Faso). A Ph.D Thesis, Department of Plant Sciences, Wageningen University, Wageningen.

Olumide, O.F. (2015). Factors Influencing Farmers' Willingness to Engage in Agroforestry Practice in Ekiti State, Nigeria. Unpublished M.Sc Dissertation, University of Nigeria, Nsukka, Nigeria.

Swindell, K. (1982). Geography of Sokoto State. Ibadan, Nigeria: Oxford University Press.

Udo, R.K. (1970).Geographical Regions of Nigeria. London: Heinemann.

World Bank. (2004). Sustaining forests: a development strategy. Retrieved from http://siteresources.worldbank.org/INTFORESTS/Resources/SustainingForests.pdf

Young, A. (1989). Agroforestry for Soil Conservation. United Kingdom. CAB International. 